\title{
Is Green the New Red? The Role of Religion in Creating a Sustainable China
}

\author{
James Miller \\ School of Religion \\ Queen's University \\ Kingston, ON \\ Canada K7L3N6
}

\begin{abstract}
The Chinese Daoist Assocation has embarked upon an ambitious agenda to promote Daoism as China's "green religion." This new construction of "green Daoism" differs, however, from both traditional Chinese and modern Western interpretations of the affinity between Daoism and nature. In promoting Daoism as a green religion, the Chinese Daoist Association is not aiming to restore some mythical utopia of humans living in harmony with nature, so much as supporting a nationalist agenda of patriotism and scientific development. At the same time, this agenda will deliver postive benefits in the form of protecting the local environments around important sacred sites that are located in areas of outstanding natural beauty.
\end{abstract}

\section{Is Green the New Red? The Role of Religion in Creating a Sustainable China}

That religion might play a role in creating a sustainable future for the world's largest emitter of greenhouse gases might seem at best to be hopelessly idealistic, and at worst a category mistake. Though the ideological frameworks espoused by China's modernizers over the past century have undergone remarkable reform and revolution, they have remained consistent in relegating religion to the arena of reactionary forces that hinder China's quest for political and economic autonomy. Religion, like global warming, the energy crisis, or social unrest, is just one more problem that China's leaders have to grapple with in steering the Chinese economy towards a peaceful and sustainable future. Despite the recent resurgence of interest in traditional Chinese culture, religion has not been emphasized. In elevating Confucius to the status of national hero, for example, China's rulers are hoping that the spiritual crisis afflicting China's people, endlessly tossed about in a swirling sea of social transformation, will be resolved by the non-theistic, non-religious, and ultimately non-threatening values of filial piety, social responsibility and educational self-improvement. The government's uncharitable and ideologically-charged view of religion is, unsurprisingly, not shared by China's religious organizations. The Chinese Daoist Association, in particular, is working to construct an image of Daoism as China's green religion and to position Daoism as a source of ecological wisdom that can make a positive contribution in China's transition to an ecologically sustainable economy. In so doing they are drawing on a wealth of philosophical insight, moral values and historical practice that is particularly relevant to the way the contemporary ecological crisis is culturally construed and represented in China. These values are oriented towards a nationalist agenda aimed at preserving elements of Chinese heritage and contributing to the future success of the Chinese nation. 
This draft essay may differ susbtantially from any future published version.

Copyright (c) 2011 James Miller. All Rights Reserved. Visit www.jamesmiller.ca

\section{Cultural Frames for the Ecological Crisis}

In examining the role that religion can play in dealing with environmental issues, it is first important to understand that the ecological crisis is not simply amenable to scientific analysis and technological remediation. The ecological crisis has consistently been construed by Western social science and humanities theorists as a cultural and even spiritual crisis: it is a crisis in the way that human beings envision themselves in relation to their natural environments; and it is a crisis that has a specific cultural genealogy and normative taxonomy. In terms of genealogy, the ecological crisis has been associated most clearly with the values of instrumental rationality that arose in the European enlightenment era. The worldview that regards the nature as having only an instrumental value in relation to human teloi and not having any intrinsic value in and of itself is, according to this analysis, a uniquely modern, Western view. On such a basis, the ecological crisis has become identified on the cultural level not as a universal problem confronting human beings everywhere and always, but as a problem identified in particular with Western intellectual history, colonial aggression and industrial development.

Given this dominant cultural framing of the ecological crisis, it is hardly surprising that modern Western devotees of "environmentalism" should look beyond the West for sources of wisdom and value in addition to critically engaging their own tradition. The cultural genealogy of the ecological crisis in fact lends itself to a normative taxonomy of ecological wisdom that privileges modernity's others. It is commonly assumed by my students, for instance, that Lynn White, Jr.'s famous essay (1967) is an indictment of Christianity as a whole: they tend to overlook White's positive framing of Franciscan Christianity because it does not fit into their normative expectations regarding the Western tradition. Conversely, they are often positively predisposed towards Asian values to be found in Buddhism or Daoism for the simple reason that they view these traditions as "others" to the dominant discourse of modernity.

The genealogical identification of the ecological crisis with Western philosophy and history entails a corresponding cultural taxonomy of non-Western marginalized "others," such as women, indigenous societies and colonized peoples. In the normative taxonomy of the ecological crisis adopted by environmentally-concerned cultural commentators in the West, these "others" become identified as possessing an ecological wisdom and living "closer to nature," often without any concrete evidence one way or the other. (As regards women's supposed affinity to nature, see Ortner 1974.) Indeed there exists a distinct body of research that questions the extent to which indigenous societies have exhibited cultures that can be construed as "environmentally friendly" by today's standards (see, for example, Pine, 1982). This in itself is evidence of the power of the cultural framing of non-Western others in relation to the natural world. As regards Daoism, for instance, Goldin (2005) takes pains to explain why "Daoism is not Environmentalism." Although this mis-titled article focusses narrowly on the philosopher Zhuangzi who cannot properly be said to represent Daoism as a whole, its significance, like others of its type referring to non-Western traditions, is that it reveal the normative cultural frame by which such traditions have come uncritically to be associated with ecology and environment. The historical fact that such societies, traditions or groups may not have been as environmentally friendly as moderns might suppose is 
culturally meaningful precisely inasmuch as it challenges the normative cultural framing of environmentalism.

This reverse-Orientalist prejudice is one reason for the role Daoism could play in China's quest for a sustainable future. Take, for instance, the way Daoism has been framed by Doris LaChapelle:

Now after all these years of gradual, deepening understanding of the [D]aoist way, I can state categorically that all these frantic last-minute efforts of our Western world to latch on to some "new idea" for saving the earth are unnecessary. It's been done for us already - thousands of years ago-by the Taoists. We can drop all that frantic effort and begin following the way of Lao Tzu [Laozi] and Chuang Tzu [Zhuangzi] (LaChapelle 1988: 349; quoted in Paper 2001: 10).

As Paper (2001) notes, this is a hopelessly simplistic view of Daoism, conflating over two thousand years of tradition with just two Daoists texts. But on the other hand, it would be wrong to dismiss the cultural power that this view may have. Indeed, the views of an academic scholar may pale in significance when faced with a dominant cultural paradigm, illinformed and uncritical though it may be. If Daoism and ecology are identified in the public imagination simply because they are viewed as others to the dominant discourse of Western modernity, the disapproval of historically sophisticated scholars may be relatively unimportant. Note here that I am not arguing in favor of a kind of expedient ignorance with respect to China's traditions. I am simply noting that one reason for the possibility of Daoism's role in China's quest for sustainability may simply be the fact that it is identified, rightly or wrongly, as an Other to the cultural hegemony of instrumental rationality.

The conceptual (respective) otherness of Chinese and Western philosophy has been noted by new Confucian intellectual Tu Weiming (2000):

The modern West's dichotomous world view (spirit/matter, mind/body, physical/mental, sacred/profane, creator/creature, God/man, subject/object is diametrically opposed to the Chinese holistic mode of thinking. ... Informed by Bacon's knowledge as power and Darwin's survival through competitiveness, the Enlightenment mentality is so radically different from any style of thought familiar to the Chinese mind that it challenges all dimensions of the Sinic world.

In this argument, $\mathrm{Tu}$ is explaining why Chinese modernizers paradoxically embraced Western values in their quest for national autonomy: it was, he argues, a strategic necessity. As such, the rejection of Chinese tradition is not, as it were, an ontological necessity for modern China, but simply an expedient necessity that may be reversed. As China experiences the downside of Western-style industrial modernization, it is no surprise that it should once again return to its traditions, in a kind of "back to the future" moment: since modernization and Westernization were conflated in the politically-expedient cultural sleight-of-hand of China's modernizers, logic would dictate that a questioning of those values should create cultural space for the reassessment and re-emergence of China's traditions. 
This draft essay may differ susbtantially from any future published version.

Copyright (c) 2011 James Miller. All Rights Reserved. Visit www.jamesmiller.ca

This is not to say, however, that the resurgence of tradition in contemporary China does not have its critics. He Zuoxiu 何祚庥, a noted theoretical physicist closely allied to the Communist Party, sparked a debate about the unscientific nature of Chinese medicine, and in 2005 engaged in a debate with environmentalists over whether or not the concept of “revering nature" (jingwei ziran 敬畏自然) was anti-scientific. He wrote (2005: 20):

I want to challenge the contention that people ought to respect and hold nature in awe, advanced by one professor. He asserts that mankind should not use science and technology to transform nature, but maintain an attitude of respect and awe. Such an attitude is "anti-science," especially when we are confronting natural disasters like the tsunami or epidemic outbreaks. I hold the opposite view. We human beings should try our best to prevent and reduce losses incurred in natural disasters. Reverence and awe make no sense.

As this excerpt notes, science is associated with humanistic progress; conversely, being "antiscience" is regarded as a kind of reactionary nonsense. This is, in fact, an argument that goes back to the early days of China's modernization. In 1915, Chen Duxiu 陈独秀, one of the founders of the Chinese Communist Party, published a famous essay in his journal New Youth (Xin qingnian 新青年), in which he called for a new kind of leader to help modernize China: someone who was independent, not servile; progressive, not conservative; aggressive not retiring; and cosmopolitan, not isolationist (see Lawrance 2004: 2-3; Miller 2006: 31). This value system was used in particular to attack China's traditional monastic forms of religion. Chen writes that "it is our natural obligation in life to advance in spite of numerous difficulties" (quoted in Lawrance 2004: 3). This meant that now was not the time to live in hermitages on remote mountainsides. In the worldview of China's modernizers, informed by Marx's theory of religion as a narcotic, to treat nature with reverent awe, or to introduce "spirituality" into environmental issues, could only be a step backwards. From such a theoretical perspective, religion cannot possibly do anything constructive in terms of dealing with environmental issues.

In responding to He's charge, however, Liang Congjie 梁从诫, the head of Friends of Nature, China's leading environmental non-governmental organization, criticized $\mathrm{He}$ Zuoxiu's humanistic, anthropocentric values. Of particular interest here is the fact that Liang saw no reason to shy away from associating reverence for nature with China's traditional values. "Numerous Chinese classical works," he writes, "have shown that we have always placed great value on nature, far more than just being a tool" (2005: 14). This theme was also invoked by Vice-Minister Pan Yue of the State Environmental Protection Agency as early as 2003. In an essay on "Environmental Culture and National Revival" he wrote that "China's environmental culture is an inheritance from and further development of traditional Chinese culture," and went on to cite numerous examples of environmental values in Confucianism, Daoism and Buddhism (2007: 6-7).

It would be a mistake, however, to interpret the association of traditional Chinese culture and environmentalism as a romantic return to some pre-modern idyll. Notwithstanding the fact that there is no clear historical evidence that traditional China was any more environmentally 
"reverent" than premodern Europe (see von Glahn 1988; Elvin 2004), the invocation of traditional Chinese values should rather be seen as a patriotic argument consistent with the development of Chinese national identity. As Pan Yue makes clear at the start of his essay (2007: 1):

The rejuvenation of the Chinese nation is a century-old dream - the unremitting pursuit of Chinese people living all over the world. A key foundation of national revival is cultural revival. The rise in the culture of environmentalism in the world creates a great opportunity for the revival of Chinese culture. The development of a socialist environmental culture with Chinese characteristics is to strive for the revival of Chinese culture and the rejuvenation of the Chinese nation.

The association of environmental values with traditional Chinese culture is thus presented as part and parcel of China's quest for self-determination. To be an environmentalist is to be a patriotic Chinese citizen and an advocate of Chinese values.

In the present ideological climate, therefore, while there is space in the cultural imagination within China and beyond for religion to play a constructive role in how humans come to envision themselves in relation to the wider environment, this space is ideologically charged - and by no means uncontested - in China in ways that are different from the West. In particular it seems that foreign religions, notably Christianity, will have little role to play; and there will be more space for Daoism to assert itself as a "green religion" not simply because of the normative taxonomy of "environmentalism" in a Western sense, but because Daoism is the indigenous religion of China. Rarely does Daoism appear in the Chinese press without the epithet "Zhongguo" (Chinese) attached to it. In the pluralist context of modern China, Daoism's unique identifier is that it is the only truly "Chinese" religion.

\section{Daoism and Ecology}

Until recently, the main way of assessing the possible contribution of Daoism to the fostering of an ecological consciousness in China was either historical or theoretical. Indeed, the volume of essays produced in the Harvard University series (Girardot et al. 2001), which I co-edited, aimed to provide evidence that that affinity between Daoism and ecology was more than a romantic wish of contemporary environmentalists for an exotic non-Western Other. Rather, environmental values were actually grounded in the worldview of Daoist religion and concretely manifested in Daoist history.

This worldview is founded on the understanding of the "Way," or Dao, a spontaneously emerging principle of cosmic creativity. This principle is manifested in the transformative powers of the natural world, leading to a core value of naturalness (ziran), and an ethic of non-assertive action (wuwei). Liu Xiaogan (2001: 324) explains the philosophical foundations of this ethic as follows:

Dao represents forever the unknown final reason of the world surrounding us, reminding human beings of their limitations. As average members of the ten thousand things in the universe, humans have no power to do what they wish 
without facing unexpected consequences. Therefore, prudent behavior and action, namely, wuwei, are important and beneficial.

The counterintuitive insight preserved in the Daoist tradition is that awareness of a fundamental mystery grounding the world should impel humans not towards technological dominance but towards creative engagement. In Liu's terms, the ethic of non-action means "better results, not pure negating of all actions" (2001: 332).

It is also instructive to consider the application of wuwei in Daoist history. Take, for example, the early Daoist religious movement known as The Way of the Celestial Masters (Tianshi dao), founded in $142 \mathrm{CE}$, which constitutes one of the two main lineages of Daoism today. In its early days, this movement functioned through a text the Celestial Masters adopted and transmitted, known as the One Hundred and Eighty Precepts (Yibai bashi jie 一百八十戒). In his study of this text, Kristofer Schipper (2001: 82-3) notes that "not less than twenty [of the precepts] are directly concerned with the preservation of the natural environment, and many others indirectly:

14. You should not burn [the vegetation] of uncultivated or cultivated fields, nor of mountains and forests.

18. You should not wantonly fell trees.

19. You should not wantonly pick herbs or flowers.

36. You should not throw poisonous substances into lakes, rivers, and seas.

47. You should not wantonly dig holes in the ground and thereby destroy the earth.

53. You should not dry up wet marshes.

79. You should not fish or hunt and thereby harm and kill living beings.

95. You should not in winter dig up hibernating animals and insects.

97. You should not wantonly climb in trees to look for nests and destroy eggs.

98. You should not use cages to trap birds and [other] animals.

100. You should not throw dirty things in wells.

101. You should not seal off pools and wells.

109. You should not light fires in the plains.

116. You should not defecate or urinate on living plants or in water that people will drink.

121. You should not wantonly or lightly take baths in rivers or seas.

125. You should not fabricate poisons and keep them in vessels.

132. You should not disturb birds and [other] animals.

134. You should not wantonly make lakes. 
In answer to the question why the earliest Daoist communities were concerned with the state of the natural environment, Schipper draws the conclusion that the natural environment functioned as a kind of sanctuary, in the sense of a sacred space, and in the sense of a place of refuge from the human world. There is also, he argues. a more fundamental point at stake here, which is evident in the language used: the precepts are directed at members of the community, and in fact we know that they were adopted as the code of practice for the heads of the Celestial Masters community, known as libationers (jijiu 祭酒). The precepts, thus, are to be understood not as abstract laws ("it is illegal to light fires in the plains"), but rather admonitions directed at the community leaders ("you should not light fires in the plains"). The implication of the imperative "you should not" is that the libationer himself, and by extension the community as a whole, will suffer the consequences of failing to abide by the precepts.

Concern for the natural landscape in which Daoist sites were located even became a matter of national pride for sites that were the subject of imperial patronage. Mt. Wudang, for instance, attained national prominence in the Ming dynasty when it came under the patronage and protection of the imperial court. The court even issued edicts in 1417 and 1428 to prevent deforestation in the area and to protect the aesthetic balance of religious architecture and natural environment (Yang 2010). Even if the imperial court was motivated narrowly by the desire to preserve a site in which it had invested much religious and financial capital, it cannot be denied that the designation of a particular space as sacred motivated concrete measures to protect the environment.

A second example can be seen at Mt. Qingcheng 青城山, now a UNESCO World Heritage Site. During a field visit in 2002, one of the several signs along the path that leads up the mountain recorded the actions of the abbot Peng Chunxian 彭椿仙 in the Repulican era of the early twentieth century. Abbot Peng decreed that all who would visit him "should plant a tree along the mountain path." This, declares the sign, demonstrates the essence of Daoism's "return to nature." Although, according to Elvin (2004: 470-471), such instances were historically the exception rather than the rule, they nonetheless provide a historical basis upon which contemporary efforts to associate Daoism and ecology can be founded.

Such official efforts by the Chinese Daoist Association (CDA) go back at least to 1995, the date of their Declaration on Global Ecology. On the final page, the declaration summarizes the ecological aims of the CDA in three bullet points:

- We shall spread the ecological teachings of Daoism, lead all Daoist followers to abide in the teachings of self-so or non-action, observe the injunction against killing for amusement purposes, preserve and protect the harmonious relationship of all things with Nature, establish paradises of immortals on Earth, and pursue the practice of our beliefs...

- We shall continue the Daoist ecological tradition by planting trees and cultivating forests. Using traditional hermitages as an organizational base, Daoists will conscientiously plant trees and build forests, thereby making 
This draft essay may differ susbtantially from any future published version.

Copyright (c) 2011 James Miller. All Rights Reserved. Visit www.jamesmiller.ca

the natural environment beautiful and transforming our hermitages into the paradise worlds of the immortals.

-We shall select some famous Daoist mountains as exemplars of the systematic task of environmental engineering. We expect to reach this goal by the early years of the new century (Zhang 2001: 370).

This statement is instructive for understanding the contemporary engagement of Daoism and ecology because it locates this engagement not, principally, in an abstract theoretical statement about the Way of nature, but rather in terms of a practical concern for "environmental engineering," which is to say, creating a particular type of environmental space that is conducive to Daoist practice. It is worth considering, then, that particular environments might have a topographical as well as historical significance in terms of the practice of Daoist religion.

Although the Daoist priestly tradition is one in which portable altars can be erected at any time and place to meet the liturgical desires of the community, the tradition has also favored specific locations and features for meditation. According to the Tang dynasty patriarch Sima Chengzhen, Daoists should meditate in chambers where light and darkness are in balance, and should sleep in rooms with their bodies facing south and their faces turned to the east (see Kohn 1987). The attention paid to the physical space in which meditation should take place, in this case the meditation chamber, gives a clue as to one reason why Daoists were anxious to preserve the natural environments in which monasteries were located. Such locations might be valuable not simply for historical reasons - that they were "sanctuaries" or "sacred spaces" inhabited by Daoists over the centuries - but because of their particular environments and topographies. Caves, for instance, are of particular importance as meditation sites because they provide a controlled environment that enable the practitioner to focus more readily on the meditative discipline of inner observation. Indeed one might even make the argument that the urban Daoist's "chamber of seclusion" was in fact modeled on the cave as the ideal space for Daoist meditation. Following this line of interpretation, it can also be argued that trees on mountains are desirable not only for aesthetic reasons, but because of their filtering effect on the sunlight: ample foliage creates a balance of yin (shade) and yang (sunlight) in the practitioner's environment and thus lends itself to successful meditation. From this perspective, Daoism can be understood as a religion that demands the preservation of very specific environmental features for the continuance of its traditions. This denotes a religious sensibility that is not always present in other religious traditions and gives a specific reason why Daoists have historically engaged in the protection of their immediate environments. In this regard it may not have been concern for nature in and of itself that motivated Daoist environmental protection efforts but rather a concern to preserve those features of the landscape that were relevant to their religious activities.

The Maoshan 茅山 Declaration of 2008 and its accompanying Eight-Year Plan represents the CDA's most recent attempt to systematize and oversee the practical engagement of Daoists with their local environments, and in so doing represents Daoist organizations and temples not simply as religious institutions but also as places of environmental education, demonstration sites of green technology, and spaces that are practically engaged with China's 
future wellbeing. It is instructive to note that the focus of these plans is not to create sustainable environments in China's rapidly expanding urban conglomerations, but to preserve a certain experience of nature in mountain Daoism. The association of Daoism and ecology is not general, but particular: it is focussed on specific sites and specific environments.

A field visit to Maoshan in 2010 gave significant insight as to the way Daoism and nature are represented together in contemporary Chinese culture. The evidence suggests that just as Daoist organizations are competing and also collaborating with local governments and other enterprises for control of the natural spaces in which monasteries are located, they are also engaged in ideological conflict over the meaning of these spaces. The battle over administrative control over natural spaces where Daoist sites are located is, like the debate between He Zuoxiu and Liang Congjie, an ideological contest over the meaning of nature. This suggests that in contemporary China, as in the West, the meaning of nature is contested in part by means of its association with concepts such as "the sacred" (see Szerzynski 2005 for discussion of this in the West). However, the precise meanings invoked in the conflict over nature and religion are somewhat different in China.

Evidence of ideological conflict can be seen in the use of signs that aim to offer visitors to Maoshan the "correct interpretation" of the natural spaces through which they are travelling. Two examples of this can be found in the Huayang Cave 华阳洞 and the Feichang Path 非常道. The Huayang cave was a site for Daoist meditation, associated in particular with the Highest Clarity Patriarch, Tao Hongjing 陶弘景 (456-536), who took as his epithet “Hermit of Huayang" (Huayang yinju 华阳 $\square$ 居). The main entrance to the Huayang Cave, however, makes no reference to the religious significance of this sacred space, noting it only as a cultural relic famous for its wall carvings dating from the Tang (608-906) to the Qing (16441911) dynasties. Presently, however, it no longer functions as a living sacred space, but as a "cultural relic" under the "protection" of the Jiangsu Province Cultural Relics Protection Unit. Another sign close gives a geological explanation for how the cave came to be formed. The uninformed observer will thus be educated solely as to the secular, scientific value of the space, whose sacred quality exists solely as a cultural memory.

A slightly different story can be found in the Feichang Path. The term "Feichang Way" or "Feichang Dao" comes from the first line of the Daode jing, which states: "The Way that can be told is not the constant Way." In Chinese, "not constant" is "Feichang 非常," and the "Feichang Way 非常道” is a newly resurfaced twisting footpath that leads from the base of the mountain to the temple on top. At regular intervals along the path, verses from the Daode jing are carved onto wooden panels, beginning with chapter 1 at the bottom, and ending with chapter 81 , the last, at the top. As climbers makes their way to the summit, they are thus engaged in a meditative encounter with the text of the Daode jing, reputed to have been authored by Laozi, the mythical sage of Daoism, later revered as a high god. The space through which the traveller passes is thus textualized and sacralized and, through the encounter with the text, a firm association between the natural beauty of the mountain and the traditions of Daoism is established in the visitor's experience. 
This association is, however, not entirely unambiguous. Along the way it is possible to see evidence of earlier texts carved in rock which have not been restored and are difficult to read. Moreover, there are several small shrines along the path which appear to have fallen into disrepair whether through deliberate neglect or otherwise. Although the mountain path is a sacred path, its sacred quality comes not from the maintenance of tradition, but rather from the presentation of a modernized form of Daoism, one that de-emphasizes concrete, material religion in favor of the more mystical and abstract verses of Daoist literature. Although Daoism and nature are represented and experienced together, it is a particularly modern, "Protestant" version of Daoism that is emphasized, in particular, a version that finds authenticity in a single founding text, rather than in the complex layers of institutional history.

Two further themes are in evidence in the Maoshan site and exist in intriguing juxtaposition to the nexus of religion and nature. The first theme to be noted is a deliberate attempt to educate people about environmental issues. Again, this is through the use of signs in Chinese and English which urge people to take care of the environment and respect the plants and animals that live in the space through which they are traveling. Such education also extends beyond the open space into the temple, where recycling bins exist side by side with regular bins, and injunctions to conserve water appear by the taps. Such small efforts at environmental education further reinforce the sense that the mountain space and the temple space are particularly deserving of careful respect. Indeed, the paved road up to the top is lit at night by lamps that are charged by solar panels during the day. This sense of environmental care, however, stands in stark contrast to the festive spirit of the many visitors whose principal objective in coming to the mountain peak is to participate in the spectacular and ostentatious offering of enormous sticks of incense. For people who do not get many opportunities to participate in traditional rituals in sacred natural spaces, it would seem particularly strange not to make as grand and joyous an offering as possible. In this sense, the "official" culture of conservation proclaimed throughout the site is studiously ignored by those for whom the site is chiefly a space for conspicuous ritual celebration.

The second theme that is juxtaposed alongside that of religion and nature, is that of nationalism. The Maoshan site is significant in modern history not for its Daoist religious associations, but as a site that is sacred to the Fourth Army in its battle against the Japanese who invaded China in 1937. During my field visit, a school of army cadets was also visiting the site, which as well as featuring temples and cultural relics, is the location for a patriotic monument and grand museum dedicated to the army. An informant told me, in fact, that the renovation of the entire site had been carried out by the People's Liberation Army, including the building of an excellent road to the monastery on the peak. As a result, the entire mountain complex is designated an AAAA tourism site, (only one step lower than the highest AAAAA designation), and it is a site for "red tourism," a program established by the central government in 2004 to emphasize the "ideological essence" of "communist ideology, traditional Chinese virtues, and patriotism" (Li and Hu 2008: 158). 


\section{Conclusions}

Historical evidence as well as contemporary fieldwork reveal a complex set of issues when it comes to the relationship of Daoism and ecology in China. These issues, furthermore, are somewhat different from what one might expect based on the normative taxonomy of "environmentalism" in relation to non-Western others, which structures popular cultural (mis-)understandings in the West. Far from Daoism's being construed as a pre-modern "worldview" sympathetic to a romantic feeling for wilderness spaces, Daoists have engaged in practical works to preserve specific natural spaces for specific religious reasons. Moreover, under the patronage of the state, whether in the Ming dynasty or today, sacred sites and their environments can also be protected for nationalistic and patriotic reasons. In these cases, the impetus to preserve the landscape of sacred sites may not derive from a particular "respect for nature" except inasmuch as the nature in question is unequivocally identified with a uniquely Chinese heritage. This would be similar to the way in which pandas are protected by the state because of their status as national icons.

Under this complex of cultural meanings, the meaning of "green" spaces such as Maoshan is quite ambiguous. On the one hand, "green" is associated with Chinese tradition and Daoist respect for life and the flourishing of nature. On the other hand, "green" is also associated with a patriotic agenda and with modern technology such as solar panels. The Chinese Daoist Association, in allying itself with a green agenda, is clearly aligning itself with the values of modern Chinese nationalism as well as technological development. In this sense, one could argue that "green is the new red": it is a symbol for Chinese national identity and the technological development that will ensure China's survival in a resource-hungry world. If Daoism has something to offer to the greening of China, it is not in the sense of fostering a worldview of a universal ecological consciousness or "saving the planet." That is a trope that owes its origins to Christian millenarian theology and has little relevance in traditional Chinese culture (Kohn 2001: 379).

Rather, Daoism and ecology engage most clearly in the particular spaces in which Daoists have sought to engage in meditative cultivation. In this regard, Daoist ecology is thoroughly implicated in Chinese national identity. While the abstract modernity of urban living is seamlessly replicated from Shanghai to Stockholm, "nature," it would seem, can no longer be construed as a universal experience. Instead, nature refers to a quality of experience that is the exception rather than the rule in the banality of modern urban life. In this regard, Daoism can make a positive and unique contribution to the preservation of green spaces in contemporary China. As John Lagerwey (2010) notes, the history of religion in China has been one of continuous contractual negotiation between the state and local society. As much as the green agenda of the Chinese Daoist Association may rhetorically serve the ideologies of nationalism and modernization, it may yet hold out the prospect of protecting marginal, local and natural spaces.

\section{List of Works Cited}

Elvin, Mark. 2004. The Retreat of the Elephants. New Haven: Yale University Press. 
Glahn, Richard von. 1998. The Country of Streams and Grottoes: Expansion, Settlement, and the Civilizing of the Sichuan Frontier in Song Times. Cambridge, MA: Harvard East Asia Monograph Series.

He Zuoxiu. 2005. “Man Need Not Revere Nature.” Friends of Nature 2005.2: 19-20.

Pine, Stephen 1982. Fire in America: A Cultural History of Wildland and Rural Fire. Princeton: Princeton University Press.

Kohn, Livia. 1987. “The Teaching of T'ien-yin-tzu." Journal of Chinese Religions 15: 1-28. . 2001. "Change Starts Small: Daoist Practice and the Ecology of Individual Lives." Pp. 373-390 in Daoism and Ecology: Ways within a Cosmic Landscape, edited by N. J. Girardot, James Miller and Liu Xiaogan. Cambridge, MA: Harvard University Press.

LaChapelle, Doris. 1988. Sacred Land, Sacred Sex: Rapture of the Deep. Finn Hill Arts. Lagerwey, John. 2010. China: A Religious State. Hong Kong: Hong Kong University Press.

Lawrance, Alan, ed. 2004. China Since 1919: Revolution and Reform. A Sourcebook. New York: Routledge.

Liang Congjie. 2005. "Is it True that Man Need Not Revere Nature." Friends of Nature 2005.2: 14-15.

Li Yiping and Hu Zhiyi. 2008. "Red Tourism in China". Journal of China Tourism Research 4.2: $156-171$.

Liu Xiaogan. 2001. "Non-Action and the Environment Today." Pp. 315-339 in Daoism and Ecology: Ways within a Cosmic Landscape edited by N. J. Girardot et al. Cambridge, MA: Harvard University Press.

Ortner, Sherry. 1974. "Is female to male as nature is to culture?" Pp. 67-87 in Woman, Culture and Society, edited by M. Z. Rosaldo and L. Lamphere. Stanford, CA: Stanford University Press.

Paper, Jordan. 2001. “'Daoism' and 'Deep Ecology': Fantasy and Potentiality.” Pp. 1-21 in Daoism and Ecology: Ways within a Cosmic Landscape, edited by N. J. Girardot, James Miller and Liu Xiaogan. Cambridge, MA: Harvard University Press.

Schippper, Kristofer. 2001. "Daoist Ecology: The Inner Transformation. A Study of the Precepts of the Early Daoist Ecclesia." Pp. 79-93 in Daoism and Ecology: Ways within a Cosmic Landscape, edited by N. J. Girardot, James Miller and Liu Xiaogan. Cambridge, MA: Harvard University Press.

Szerszynski, Bronislaw. 2005. Nature, Technology and the Sacred. Oxford: Blackwell.

White, Lynn Jr. 1967. “The Historical Roots of Our Ecologic Crisis.” Science 155: 12031207 ,

Yang Lizhi 杨立志. 2010. “Mingdai Wudangshan de shengtai huanjing baohu ji qi xiandai qishi 明代武当山的生态环境保护及其现代启示 [Environmental Protection on Mt. 
This draft essay may differ susbtantially from any future published version.

Copyright (c) 2011 James Miller. All Rights Reserved. Visit www.jamesmiller.ca

Wudang in the Ming Dynasty and its Modern Relevance]." Conference on Daoism Today: Science, Health, Ecology. Los Angeles: Loyola Marymount University, June 2-6. 